\title{
The efficacy of thymosin a1 as immunomodulatory treatment for sepsis: a systematic review of randomized controlled trials
}

Fang Liu', Hong-Mei Wang ${ }^{1,2}$, Tiansheng Wang ${ }^{3}$, Ya-Mei Zhang ${ }^{1}$ and Xi Zhu ${ }^{4^{*}}$

\begin{abstract}
Background: Thymosin a1 (Ta1) as immunomodulatory treatment is supposed to be beneficial for the sepsis patients by regulating $T$ cell subsets and inflammatory mediators. However, limited by the small sample size and the poor study design, the persuasive power of the single clinical studies is weak. This meta-analysis aimed to investigate the impact of Ta1 on the sepsis patients.

Methods: We searched for the Cochrane Central Register of Controlled Trials, MEDLINE, EMBASE, CBM, VIP, CNKI, WANFANG, Igaku Chuo Zasshi (ICHUSHI) and Korean literature databases reporting the effects of Ta1 on outcomes in sepsis patients.

Results: Among 444 related articles, 19 randomized controlled trials (RCTs) met our inclusion criteria. Mortality events were reported in 10 RCTs included 530 patients, and the meta-analysis showed significant decrease in Ta1 group compared with control group (RR $0.59,95 \% \mathrm{Cl} 0.45$ to $0.77, p=0.0001$ ). The subgroup analysis showed no difference between the two dosages (RR $0.59,95 \% \mathrm{Cl} 0.43$ to 0.81 ; RR $0.59,95 \% \mathrm{Cl} 0.35$ to 0.98 , respectively). In 9 RCTs, with a total of 489 patients, Ta1 administered once per day decrease APACHE II score significantly (SMD -0 . $80,95 \% \mathrm{Cl}-1.14$ to $-0.47, p<0.0001$ ) while Ta1 twice per day showed no effect (SMD 0.30, $95 \% \mathrm{Cl}-0.10$ to 0.70 , $p=0.14$ ). However, the length of ICU stay, the incidence of multiple organ failure (MOF) and duration of mechanical ventilation were not significantly affected by Ta1 treatment (SMD $-0.52,95 \% \mathrm{Cl}-1.06$ to $0.11, p=0.06$; SMD -0.49 , $95 \% \mathrm{Cl}-1.09$ to $0.11, p=0.11$; SMD $-0.37,95 \% \mathrm{Cl}-0.90$ to $0.17, p=0.17$, respectively). As to the immunological indicators, the level of HLA-DR were increased by Ta1 (SMD 1.23, $95 \% \mathrm{Cl} 0.28$ to $2.18, p=0.01$ ) according to the pooled analysis of 8 studies involving 721 patients. Lymphocyte subsets CD3, CD4 and cytokines IL-6, IL-10 and TNF-a were also beneficially affected by Ta1 treatment.
\end{abstract}

Conclusions: Ta1 may be beneficial to sepsis patients in reducing mortality and modulating inflammation reactions. However, the quality of evidence supporting the effectiveness is low considering the small sample sizes and inadequate adherence to standardized reporting guidelines for RCTs among the included studies.

Keywords: Thymosin a1, Sepsis, Systematic review, Immunomodulatory

\footnotetext{
*Correspondence: xizhuccm@163.com

${ }^{4}$ Department of Critical Care Medicine, Peking University Third Hospital, 49

North Garden Road, Haidian District, Beijing 100191, China

Full list of author information is available at the end of the article
} 


\section{Background}

Sepsis is a major cause of morbidity and mortality in developed countries [1]. The mechanism of the sepsis syndrome is not completely understood though we do know it includes a systematic immune system response in multiple and complex pathways which is named SIRS (Systemic Inflammatory Reaction Syndrome) [2, 3]. Sepsis begins with epitope shifting from antigen presenting cells into neutrophils, macrophages and $\mathrm{T}$ helper lymphocytes (Th), followed by cell transcription factor NF-k $\mathrm{B}$ activating, entering nucleus and forming a complex with DNA. Subsequently, apoptosis is induced and Th lymphocytes is activated into Thl cells, which release a large amount of proinflammatory cytokines and chemokines, such as TNF- $\alpha$, IL-6, IL- $1 \beta$, IFN- $\gamma$ and monocyte chemoattractant protein (MCP-1), then complement and coagulation system were activated, and systematic inflammation was developed, leading to high fever, shock, coagulation dysfunction and multiple organ failure, and even death [4-6].

Thymosin $\alpha 1$ (T $\alpha 1)$ is an acidic polypeptide consisting of 28 amino acids extracted and purified from the thymosin fraction 5. Pharmacological studies showed that T $\alpha 1$ stimulates endogenous IFN- $\gamma$ secretion, and enhances $\mathrm{T}$ cells and the whole immune system [7-12]. Pharmacokinetic studies in healthy volunteers showed good absorption after subcutaneous injection with a peak serum level at between 1 and $2 \mathrm{~h}$ and a half-life of less than three hours [13]. T 1 is approved mainly in countries of Asia and South America, for the treatment of chronic hepatitis $B$ and $C$ as a vaccine enhancer [14]. Although some clinical trials demonstrated that $T \alpha 1$ is beneficial for the treatment of sepsis by regulating $\mathrm{T}$ cell subsets and inflammatory mediators [15-17], the results are less persuasive due to the small sample size and the poor study design. As the influence of T $\alpha 1$ on prognosis of patients with sepsis remains inconclusive, this systematic review aims to quantitatively evaluate the efficacy and safety of T $\alpha 1$ in the treatment of sepsis.

\section{Methods}

\section{Inclusion criteria}

Studies are included if the following criteria are met: 1) Randomized controlled trials (RCTs); 2) Evaluating adult sepsis patients. We defined sepsis according to internationally accepted diagnostic criteria developed on 2001 SCCM/ESICM/ACCP/ATS/SIS international sepsis definitions conference [18]. 3) Comparing T $\alpha 1$ as add on therapy with no treatment or placebo on the basis of standard or conventional treatment of sepsis in both groups. Standard or conventional treatment is defined as regular treatment for sepsis including adequate empiric antibiotic therapy, ventilation regimen, blood glucose control, resuscitation and hemodynamic support, organ support, sedation or analgesia as needed and adequate nutrition.

\section{Outcome measures}

The primary outcomes are death from any cause assessed 28,60 and 90 days after the initiation of treatment assignment, the length of ventilation and the length of ICU staying. The secondary outcomes included dynamic changes of Sequential Organ Failure Assessment (SOFA), multiple organ dysfunction syndrome (MODS), Acute Physiology and Chronic Health Evaluation II (APACHE II), T lymphocyte subsets, $\mathrm{CD} 4^{+} / \mathrm{CD}^{+}$, monocyte human leukocyte antigen-DR (mHLA-DR) expression, and cytokines including IL-6, IL-10 and TNF- $\alpha$ measured on day 0 (the day of enrollment) and 7 in both groups. The rate of adverse drug reactions was taken as indicator for tolerability.

\section{Search strategy}

We searched Cochrane Central Register of Controlled Trials (CENTRAL) (The Cochrane Library, Issue 3 of 12, March 2016), MEDLINE (January 1966 to April 19, 2016), EMBASE (January 1980 to April 19, 2016) for published studies and Clinicaltrials for registered studies in English [19]. We searched China National Knowledge Infrastructure (CBM), VIP Database for Chinese Technical Periodicals (VIP), Chinese National Knowledge Infrastructure (CNKI) and Wanfang Data in Chinese, all from inception to April 19, 2016. We searched Igaku Chuo Zasshi (ICHUSHI) for Japanese literature, and Korean literature up to February 12, 2015 [20]. We checked the bibliographies in reports of the randomized trials, review articles, and meta-analyses to identify other potentially eligible studies. We used a combination of keywords related to the names of thymosin $\alpha 1$ (T $\alpha 1$ or Thymosin-alpha (1) or Thymalfasin or Thymalfasine or Thymalsasinum or Timalfasina or Zadaxin) and the type of sepsis-associated disease ("severe infection" or "sepsis" or "septic shock").

\section{Study selection}

Two review authors (FL and HMW) checked titles and abstracts identified from the register, obtained the full text of all potentially relevant studies for independent assessment. The authors decided independently which trials fitted the inclusion criteria and resolved disagreements by discussion or consulting the third author (XZ). The reasons for excluding studies from the review were documented and justified.

\section{Data extraction and management}

Two review authors (FL and HMW) performed data extraction independently with a pre-tested electronic table. Discrepancies were resolved by consensus or a third author's (XZ) adjudication. The following data were abstracted from each study: characteristics of the studies, characteristics of the included patients and outcomes of the studies. The first or corresponding author of each 
included study was contacted for clarifications and further information when required.

\section{Assessment of risk of bias in included studies}

We used a domain-based evaluation as recommended by the Cochrane Handbook 5.0.2 for Systematic Reviews of Interventions [21]. The following domains were assessed: 1 ) random sequence generation; 2) allocation concealment; 3) blinding of participants, personnel and outcome assessors; 4) incomplete outcome data; 5) Selective reporting. 6) Bias from other source. We graded these items as having high, low or unclear risk. When discrepancies between review authors existed, we reassessed the studies and reached agreement by consensus.

\section{Statistical analysis}

We calculated the treatment effect across trials using the Cochrane statistical package, Review Manager 5.3 (RevMan). We expressed results as risk ratios (RR) with $95 \%$ confidence intervals (CIs) for dichotomous outcomes, such as mortality, and mean differences (MDs) and $95 \%$ CIs for continuous outcomes, such as the length of ventilation, the scores of the evaluation scales, the counts of lymphocytes subsets and the concentration of cytokines. Heterogeneity among studies was assessed using a $\mathrm{Chi}^{2}$ test of heterogeneity $(P$ value $<0.1)$ and the $\mathrm{I}^{2}$ statistic [22].

Trials comparing similar regimens were pooled using fixed effect model, unless significant heterogeneity was observed when useing random-effects model. If the mean and $\mathrm{SD}$ of the continuous outcomes were not reported in the studies, we assigned the median as the mean if sample size was greater than 25 and estimated the SD from the range (that is, SD range $0.95 / 4$ or interquartile range/1.35) as suggested by Hozo et al. [23]. If sample size was less than 25 we used formulas suggested by Hozo et al. to calculate the mean [23]. If we could not calculate the mean or SD from the available data, we excluded the study from the analysis.

\section{Sensitivity analysis}

We undertook sensitivity analyses taking into account the quality of the studies. To evaluate a single study's effect on the pooled data, sensitivity analysis was carried out by excluding each study. Publication bias was evaluated using Funnel plots and Fail-Safe Number (Nfs) [24].

\section{Subgroup analysis and investigation of heterogeneity}

We explored sources of heterogeneity with a priori subgroup hypotheses: dosage regimen of T $\alpha 1$. Patients received subcutaneous injections of $1.6 \mathrm{mg}$ T $\alpha 1$ (ZADAXIN $^{\mathrm{m}}$, SciClone Pharmaceuticals, Foster City, CA, USA) twice per day for 5 consecutive days, then once per day for 2 consecutive days.

\section{Results}

Characteristics of included studies

From electronic searches and hand searches,we retrieved 444 relevant publications. A total of 248 articles were obtained from initial screening, and 19 RCTs involving 1354 adult patients were included in the meta-analysis. A detailed flowchart of the search and selection results is shown in Fig. 1. All the included studies [25-43] were conducted in China. The key characteristics of included trials were summarized in Table 1. The prior or preexisting conditions were addressed as burn, hospital-acquired pulmonary infection and abdominal infection respectively in three studies $[28,29,37]$, however, the patients included in these studies comply the diagnosis criteria of sepsis. Of the 19 RCTs, 14 included studies [25-36, 42, 43] used T $\alpha 11.6 \mathrm{mg}$ per day and 5 studies [37-41] used $1.6 \mathrm{mg}$, twice per day, both administered subcutaneously.

\section{Risk of bias in included studies}

The quality of the included studies was assessed using the criteria defined in the Cochrane Handbook 5.0.2 [21]. The assessments and grades given are shown in Table 2. Only 2 out of 19 trials were considered as high quality.

\section{The impact on mortality}

None of the included studies reported 60 and 90-day mortality.

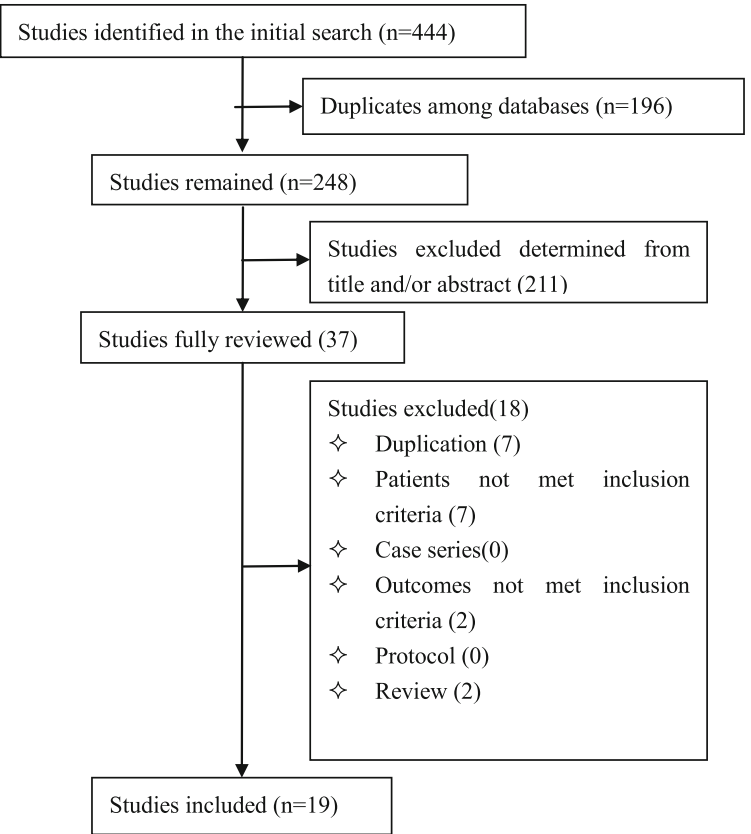

Fig. 1 Flow diagram for study selection. A detailed flowchart of the search and selection results is shown in this figure 
Table 1 Characteristics of included studies. SSC therapy: Surviving Sepisis Campaign therapy

\begin{tabular}{|c|c|c|c|c|c|}
\hline Study & Population & $\begin{array}{l}\text { Case number, Ta1/ } \\
\text { control }\end{array}$ & $\begin{array}{l}\text { Interventions } \\
\text { in Ta1 group }\end{array}$ & $\begin{array}{l}\text { Interventions in } \\
\text { control group }\end{array}$ & Outcomes \\
\hline $\begin{array}{l}\text { Chen } \\
\text { XL 2009 [25] }\end{array}$ & $\begin{array}{l}\text { Sepsis patients in ICU, } \\
\text { age over } 18 \text { years }\end{array}$ & $40,20 / 20$ & SSC therapy + Ta1, $1.6 \mathrm{mg}, \mathrm{SC}, \mathrm{QD}$ & SSC therapy + NS & Levels of CD3,CD4,CD8, CD4/CD8, NK,CRP, APACHE ॥ \\
\hline $\begin{array}{l}\text { Cheng AB } 2010 \\
{[26]}\end{array}$ & $\begin{array}{l}\text { Sepsis patients in ICU, } \\
\text { age under } 70 \text { years and } \\
\text { HLA-DR }<30 \%\end{array}$ & $60,30 / 30$ & $\begin{array}{l}\text { Conventional treatment + Ta1, } \\
1.6 \mathrm{mg}, \mathrm{SC}, \mathrm{QD}\end{array}$ & $\begin{array}{l}\text { Conventional } \\
\text { treatment + NS }\end{array}$ & Levels of CD4,CD8 and HLA-DR \\
\hline $\begin{array}{l}\text { Gui CM } 2012 \\
\text { [27] }\end{array}$ & $\begin{array}{l}\text { Sepsis patients in ICU, } \\
\text { age between } 18 \text { and } \\
80 \text { years }\end{array}$ & $42,22 / 20$ & SSC therapy + Ta1, $1.6 \mathrm{mg}, \mathrm{SC}, \mathrm{QD}$ & SSC therapy & $\begin{array}{l}\text { Levels of CD4, CD4/CD8, igg, iga, igm, PCT, IL-6, } \\
\text { IL-10 and APACHE ॥ }\end{array}$ \\
\hline $\begin{array}{l}\mathrm{Hu} X \mathrm{XL} 2007 \\
{[28]}\end{array}$ & $\begin{array}{l}\text { Abdominal sepsis } \\
\text { patients in ICU }\end{array}$ & $45,24 / 21$ & $\begin{array}{l}\text { Conventional treatment + Ta1, } \\
1.6 \mathrm{mg}, \mathrm{SC}, \mathrm{QD}\end{array}$ & $\begin{array}{l}\text { Conventional } \\
\text { treatment + NS }\end{array}$ & $\begin{array}{l}\text { Levels of TNF-a, IL-6, IL-10, CD3,CD4,CD8, CD4/CD8, } \\
\text { NK and 28-day mortality }\end{array}$ \\
\hline $\begin{array}{l}\text { Gong ZH } 2011 \\
{[29]}\end{array}$ & Burn sepsis patients & $56,28 / 28$ & $\begin{array}{l}\text { Conventional treatment + Ta1, } \\
1.6 \text { mg, SC, QD }\end{array}$ & $\begin{array}{l}\text { Conventional } \\
\text { treatment }\end{array}$ & Levels of TNF-a, and WBC \\
\hline $\begin{array}{l}\text { Chen J } 2007 \\
\text { [38] }\end{array}$ & $\begin{array}{l}\text { Septic shock, APACHE II } \\
\text { scores between } 15 \text { and } 20\end{array}$ & $42,21 / 21$ & SSC therapy + Ta1, 1.6 mg,SC, BID & SSC therapy & $\begin{array}{l}\text { Levels of T-lymphocyte subtype, natural killer cell } \\
\text { and mechanical ventilation time, length of ICU stay, } \\
\text { 28-day mortality }\end{array}$ \\
\hline $\begin{array}{l}\text { Fan JB } 2014 \\
\text { [30] }\end{array}$ & $\begin{array}{l}\text { Sepsis patients or septic } \\
\text { shock }\end{array}$ & $120,60 / 60$ & $\begin{array}{l}\text { Conventional treatment + Ta1, } \\
1.6 \mathrm{mg}, \mathrm{SC}, \mathrm{QD}\end{array}$ & $\begin{array}{l}\text { Conventional } \\
\text { treatment }\end{array}$ & $\begin{array}{l}\text { Levels of CD4, CD8, CD4/CD8, APACHE II and 28-day } \\
\text { mortality }\end{array}$ \\
\hline Lei S 2005 [37] & $\begin{array}{l}\text { Severe hospital acquired } \\
\text { pneumonia patients in ICU, } \\
\text { HLA-DR }<30 \% \text {, }\end{array}$ & $38,21 / 17$ & $\begin{array}{l}\text { Conventional treatment + Ta1, } \\
1.6 \mathrm{mg}, \mathrm{SC}, \mathrm{BID}\end{array}$ & $\begin{array}{l}\text { Conventional } \\
\text { treatment }\end{array}$ & $\begin{array}{l}\text { Levels of CD4, CD8, CD4/CD8, NK, HLA-DR and 28-day } \\
\text { mortality }\end{array}$ \\
\hline Li YN 2009 [31] & $\begin{array}{l}\text { Age over } 18 \text { years, suffering } \\
\text { from severe sepsis with } \\
\text { Marshall score over } 5\end{array}$ & $47,23 / 24$ & SSC therapy + Ta1, 1.6 mg,SC, QD & SSC therapy & $\begin{array}{l}\text { Levels of HLA-DR, CD3, CD4, CD8, length of ICU stay, } \\
\text { APACHE II, 28-day mortality and mechanical ventilation time }\end{array}$ \\
\hline $\begin{array}{l}\text { Wu JN } 2004 \\
{[32]}\end{array}$ & $\begin{array}{l}\text { Sepsis patients in ICU, } \\
\text { HLA-DR }<30 \%\end{array}$ & $44,22 / 22$ & $\begin{array}{l}\text { Conventional treatment + Ta1, } \\
1.6 \mathrm{mg}, \mathrm{SC}, \mathrm{QD}\end{array}$ & $\begin{array}{l}\text { Conventional } \\
\text { treatment + NS }\end{array}$ & Levels of HLA-DR, CRP, APACHE II; and MOF \\
\hline $\begin{array}{l}\text { Wu JF } 2013 \\
{[39]}\end{array}$ & $\begin{array}{l}\text { Patients in ICU with severe } \\
\text { sepsis }\end{array}$ & $361,181 / 180$ & $\begin{array}{l}\text { Conventional treatment }+ \text { Ta1, } \\
1.6 \mathrm{mg} \text {, SC, twice per day for } 5 \\
\text { consecutive days, then once per } \\
\text { day for } 2 \text { consecutive days }\end{array}$ & $\begin{array}{l}\text { Conventional } \\
\text { treatment + NS }\end{array}$ & $\begin{array}{l}\text { Levels of HLA-DR, CD4/CD8, WBC, duration of ICU stay, } \\
\text { mechanical ventilation time, APACHE II and 28-day mortality }\end{array}$ \\
\hline $\begin{array}{l}\text { Wu JF } 2014 \\
{[40]}\end{array}$ & $\begin{array}{l}\text { Sepsis patients, age over } \\
18 \text { years }\end{array}$ & $54,26 / 28$ & $\begin{array}{l}\text { Conventional treatment }+ \text { Ta } 1 \text {, } \\
1.6 \mathrm{mg} \text {, SC, twice per day for } \\
5 \text { consecutive days, then once per } \\
\text { day for } 2 \text { consecutive days }\end{array}$ & $\begin{array}{l}\text { Conventional } \\
\text { treatment }\end{array}$ & 28-day mortality \\
\hline $\begin{array}{l}\text { Zhang BJ } 2014 \\
\text { [41] }\end{array}$ & Sepsis patients & $60,30 / 30$ & $\begin{array}{l}\text { Conventional treatment }+ \text { Ta1, } 1.6 \mathrm{mg}, \mathrm{SC} \text {, } \\
\text { twice per day }\end{array}$ & $\begin{array}{l}\text { Conventional } \\
\text { treatment }\end{array}$ & Level of IL- 6 and APACHE ॥ \\
\hline $\begin{array}{l}\text { Zhang Z } 2006 \\
\text { [33] }\end{array}$ & Sepsis patients & $38,19 / 19$ & $\begin{array}{l}\text { Conventional treatment + Ta1, } 1.6 \mathrm{mg}, \mathrm{SC} \text {, } \\
\mathrm{QD}\end{array}$ & $\begin{array}{l}\text { Conventional } \\
\text { treatment }\end{array}$ & Levels of CRP, CD3, CD4, CD8, CD4/CD8, NK, and APACHE II \\
\hline $\begin{array}{l}\text { Zhou LX } 2009 \\
\text { [35] }\end{array}$ & $\begin{array}{l}\text { Severe sepsis aged }>18 \\
\text { Marshall score }>5\end{array}$ & $47,23 / 24$ & Ta1 plus SSC therapy & SSC therapy & IL-6, IL-10, TNF-a, HLA-DR, T lymphocytes, 28-day mortality \\
\hline $\begin{array}{l}\text { Zhao MY } 2007 \\
{[34]}\end{array}$ & $\begin{array}{l}\text { Sepsis patients in ICU, } \\
\text { HLA-DR }<30 \% \text {, age }<70\end{array}$ & $42,21 / 21$ & $\begin{array}{l}\text { Conventional treatment + Ta1, } 1.6 \mathrm{mg} \\
\mathrm{SC}, \mathrm{QD}\end{array}$ & $\begin{array}{l}\text { Conventional } \\
\text { treatment + NS }\end{array}$ & Levels of HLA-DR, CD4, CD8, TNF-a,lL-6 and IL-10 \\
\hline
\end{tabular}


Table 1 Characteristics of included studies. SSC therapy: Surviving Sepisis Campaign therapy (Continued)

\begin{tabular}{|c|c|c|c|c|c|}
\hline $\begin{array}{l}\text { Zhou Q } 2011 \\
\text { [36] }\end{array}$ & $\begin{array}{l}\text { Severe sepsis, age }> \\
18 \text { years }\end{array}$ & $82,42 / 40$ & SSC therapy + Ta1, $1.6 \mathrm{mg}, \mathrm{SC}, \mathrm{QD}$ & SSC therapy & Levels of HLA-DR, CD3, CD4, CD8, CD4/CD8 \\
\hline Zhu 2015 [43] & $\begin{array}{l}\text { Severe sepsis, age }> \\
18 \text { years }\end{array}$ & $60,30 / 30$ & $\begin{array}{l}\text { Conventional treatment + Ta1, } \\
1.6 \text { mg, SC, QD }\end{array}$ & $\begin{array}{l}\text { Conventional } \\
\text { treatment + NS }\end{array}$ & $\begin{array}{l}\text { Levels of, CD3, CD4, CD8, CD4/CD8, } \\
\text { duration of ICU stay and APACHE ॥ }\end{array}$ \\
\hline Lu 2015 [42] & $\begin{array}{l}\text { Patients with siai, age }> \\
18 \text { years }\end{array}$ & $76,38 / 38$ & $\begin{array}{l}\text { Conventional treatment + Ta1, } \\
1.6 \text { mg, SC, twice a week }\end{array}$ & $\begin{array}{l}\text { Conventional } \\
\text { treatment + NS }\end{array}$ & Levels of, CD3, CD4, CD8, CD4/CD8 \\
\hline
\end{tabular}


Table 2 Risk of bias in include studies

\begin{tabular}{|c|c|c|c|c|c|c|c|c|c|}
\hline $\begin{array}{l}\text { The first } \\
\text { author }\end{array}$ & $\begin{array}{l}\text { Publication } \\
\text { year }\end{array}$ & $\begin{array}{l}\text { Adequate } \\
\text { sequence } \\
\text { generation }\end{array}$ & $\begin{array}{l}\text { Allocation } \\
\text { concealment }\end{array}$ & $\begin{array}{l}\text { Blinding } \\
\text { (Participant) }\end{array}$ & $\begin{array}{l}\text { Blinding } \\
\text { (Personnel) }\end{array}$ & $\begin{array}{l}\text { Blinding } \\
\text { (Outcome } \\
\text { assessor) }\end{array}$ & $\begin{array}{l}\text { Incomplete } \\
\text { outcome data } \\
\text { (attrition bias) }\end{array}$ & $\begin{array}{l}\text { Selective reporting } \\
\text { (reporting bias) }\end{array}$ & Other bias \\
\hline Chen XL & 2009 & Unclear & Unclear & Unclear & Unclear & Unclear & Low risk & Low risk & Low risk \\
\hline Cheng $A B$ & 2010 & Unclear & Unclear & Unclear & Unclear & Unclear & Unclear & Low risk & Low risk \\
\hline Gui CM & 2012 & High risk & High risk & Unclear & Unclear & Unclear & Low risk & Low risk & Low risk \\
\hline $\mathrm{Hu} X Y$ & 2007 & Unclear & Unclear & Unclear & Unclear & Unclear & Unclear & Low risk & Low risk \\
\hline Gong ZH & 2011 & Low risk & Unclear & Unclear & Unclear & Unclear & Low risk & Low risk & Low risk \\
\hline Chen J & 2007 & Unclear & Unclear & Unclear & Unclear & Unclear & Low risk & Low risk & Low risk \\
\hline Fan JB & 2014 & Unclear & Unclear & Unclear & Unclear & Unclear & Unclear & Low risk & Low risk \\
\hline Lei $\mathrm{S}$ & 2005 & Unclear & Unclear & Unclear & Unclear & Unclear & Unclear & Low risk & Low risk \\
\hline Li YN & 2009 & Unclear & Unclear & Unclear & Unclear & Unclear & Low risk & Low risk & Low risk \\
\hline Wu JN & 2004 & Low risk & Low risk & Unclear & Unclear & Unclear & Unclear & Low risk & Low risk \\
\hline Wu JF & 2013 & Low risk & Low risk & Low risk & Low risk & Low risk & Low risk & Low risk & Low risk \\
\hline Wu JF & 2014 & Low risk & Low risk & Low risk & Low risk & Low risk & Low risk & Low risk & Low risk \\
\hline Zhang BJ & 2014 & Unclear & Unclear & Unclear & Unclear & Unclear & Low risk & Low risk & Low risk \\
\hline Zhang Z & 2006 & Unclear & Unclear & Unclear & Unclear & Unclear & Unclear & Low risk & Low risk \\
\hline Zhou LX & 2009 & Unclear & Unclear & Unclear & Unclear & Unclear & Low risk & Low risk & Low risk \\
\hline Zhao MY & 2007 & Low risk & Low risk & Unclear & Unclear & Unclear & Low risk & Low risk & Low risk \\
\hline Zhou Q & 2011 & Low risk & Low risk & Unclear & Unclear & Unclear & Low risk & Low risk & Low risk \\
\hline Zhu SJ & 2015 & Unclear & Unclear & Unclear & Unclear & Unclear & Low risk & Low risk & Low risk \\
\hline Lu FP & 2015 & Unclear & Unclear & Unclear & Unclear & Unclear & Low risk & Low risk & Low risk \\
\hline
\end{tabular}

\section{Primary analysis of 28-day mortality}

A total of 10 studies reported mortality within 28 days, including a total of 530 patients and 158 events (Fig. 2). No significant heterogeneity was found across the 10 studies (Chi 3.81, $\mathrm{I}^{2} 0 \%, p=0.92$ ). Furthermore, we detected no evidence of publication bias after a funnel plot analysis (Fig. 3), and $\mathrm{Nfs}_{0.05}=36.04$. The RR showed a

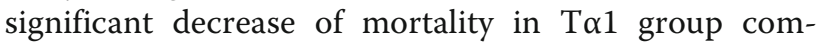
pared with control group (RR 0.59, $95 \%$ CI 0.45 to 0.77, $p=0.0001$ ) (Fig. 2).

\section{Subgroup analysis of 28-day mortality}

To explore the relationship between different dose of T $\alpha 1$ and 28-day mortality, we conducted the subgroup analyses. The intervention of T $\alpha 1$ administered once per day was adopted in 7 trials involving 396 patients and the intervention of T $\alpha 1$ administered twice per day was adopted in three trials involving 134 patients. The subgroup analysis showed both the two dosage regimens significantly decreased mortality of sepsis patients (T $\alpha 1$ once per day: RR $0.59,95 \%$ CI 0.43 to 0.81 ; T 1 twice per day: RR 0.59, 95 \% CI 0.35 to 0.98 ) (Fig. 2).

\section{The impact on APACHE II}

\section{Primary analysis}

Nine studies involving 489 patients reported APACHE II score. There was a significant difference in APACHE II score reduction between T 1 and control group (SMD $-0.55,95 \%$ CI -0.97 to $-0.13, p=0.01$ ), which meant that T 1 decreased APACHE II in a greater degree than control group. Since the heterogeneity was high (Chi 39.82, I ${ }^{2} 80 \%$ ) (Fig. 4) among different studies, we conducted subgroup analysis.

\section{Subgroup analysis}

The intervention of T $\alpha 1$ administered once per day was adopted in 7 trials involving 391 patients and the intervention of T $\alpha 1$ twice per day was adopted in two trials involving 98 patients (Fig. 4).

SMD for T $\alpha 1$ once per day group was -0.80 (95\% CI -1.14 to $-0.47, p<0.00001)$ with a moderate heterogeneity (Chi 14.26, $\mathrm{I}^{2} 58 \%, p=0.03$ ).

However, the effect of T $\alpha 1$ twice per day on APACHE II was not statistically significant (SMD 0.30, $95 \%$ CI-0.10 to $0.70, p=0.14)$. No significant heterogeneity was found across the 2 studies (Chi $0.34, \mathrm{I}^{2} 0 \%, p=0.56$ ).

\section{The impact on MOF}

Only one study involving 44 patients reported the incidence of multiple organ failure (MOF). As shown in Table 3, there was no significant difference on MOF between $\mathrm{T} \alpha 1$ and control group. (SMD -0.49, $95 \%$ CI -1.09 to $0.11, p=0.11$ ). 


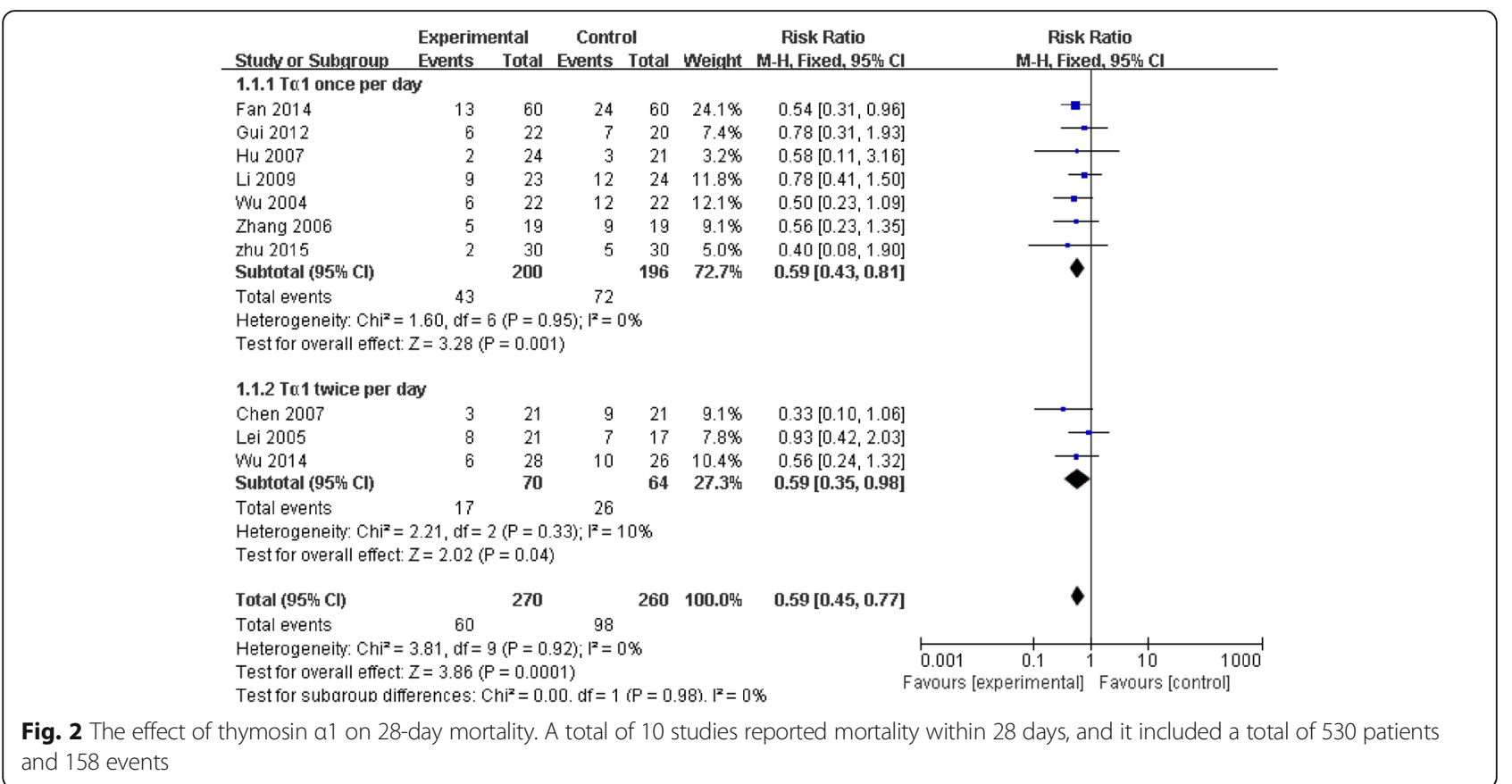

\section{The impact on mechanical ventilation days}

Six studies reported duration of mechanical ventilation, and a total of 570 patients were included. As shown in Table 3, there was no significant difference on the mechanical ventilation days between $\mathrm{T} \alpha 1$ and control group (SMD -0.37, $95 \%$ CI -0.90 to $0.17, p=0.17$ ). However, heterogeneity was high (Chi 32.24, $\left.\mathrm{I}^{2} 84 \%, p<0.001\right)$.

\section{The impact on length of ICU stay}

Six studies involving 591 patients reported the length of ICU stay. As shown in Table 3, there was no significant difference on the length of ICU stay between T $\alpha 1$ and control group. SMD was -0.52 (95 \% CI -1.06 to $0.01, p=0.06)$ with high heterogeneity (Chi 34.92, $\mathrm{I}^{2}$ $86 \%, p<0.0001)$.

\section{The impact on HLA-DR levels}

Eight studies including 721 patients reported the level of HLA-DR. There was a significant difference in HLADR between T $\alpha 1$ and control group. SMD was 1.23 (95 $\%$ CI 0.28 to $2.18, p=0.01$ ), with a high heterogeneity (Chi 179.65, $\mathrm{I}^{2} 96 \%$ ) (Fig. 4). To explore the high heterogeneity among different studies, we conducted subgroup analysis.

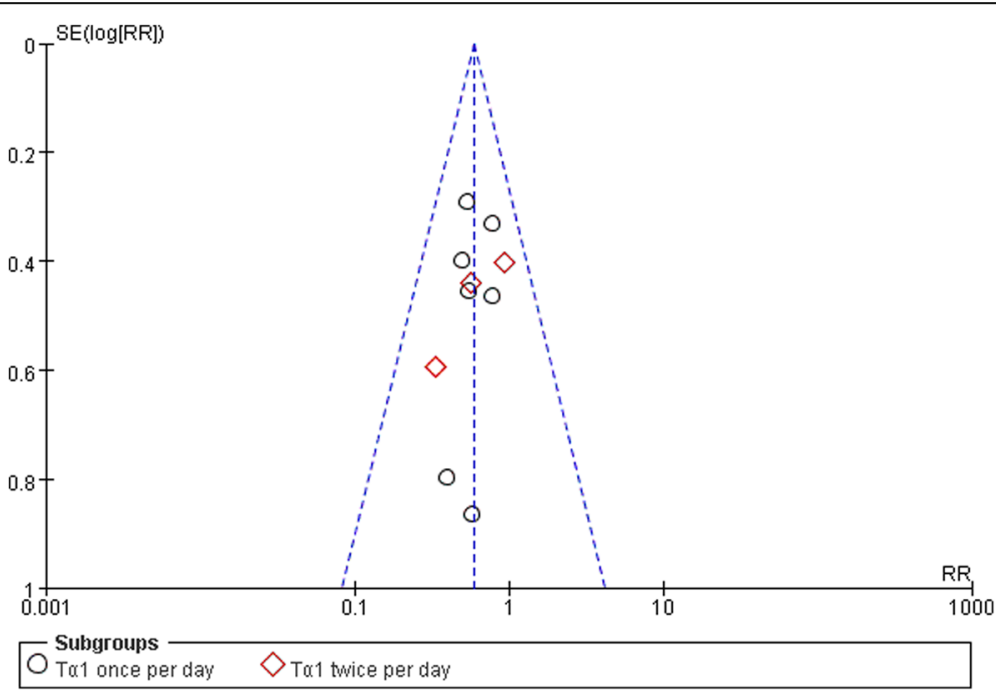

Fig. 3 Funnel plot of the published studies in relation to the 28-day mortality meta-analysis. Ten studies were included. No evidence of a publication bias in a funnel plot analysis 


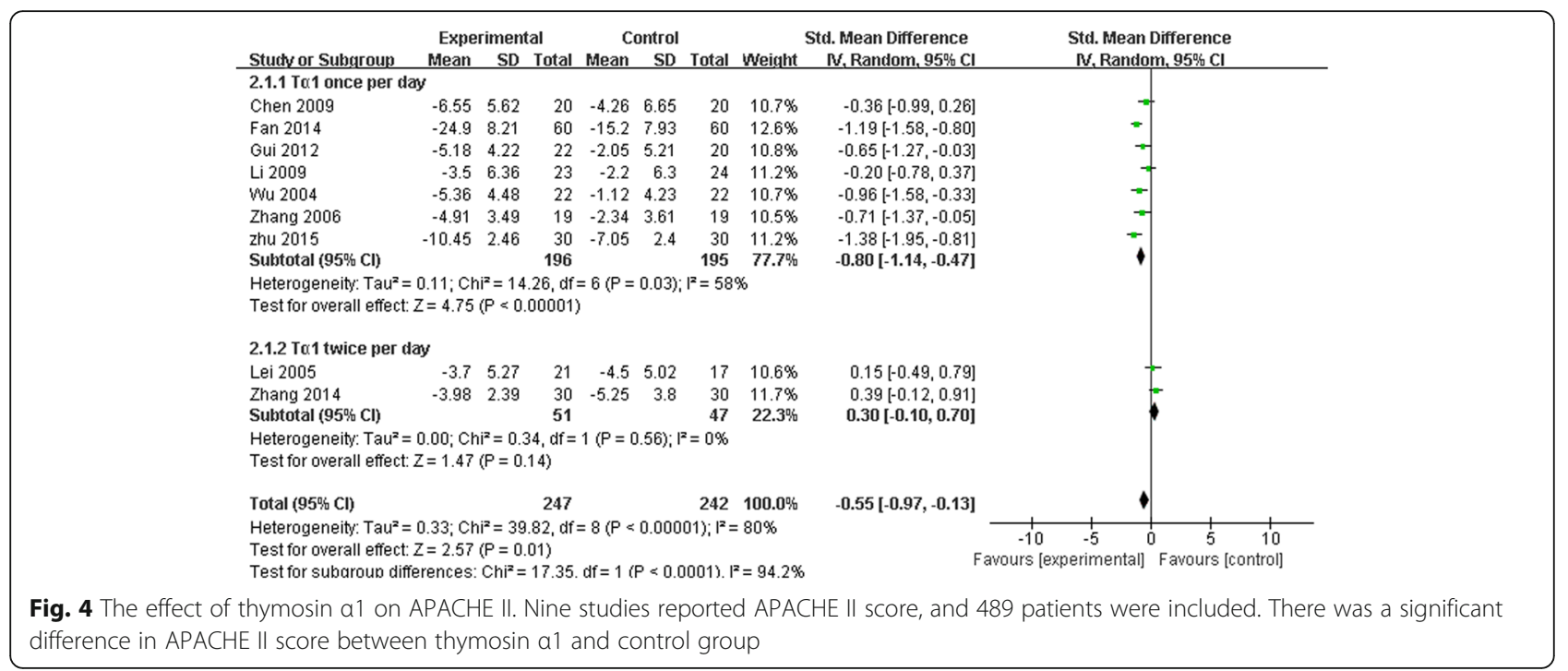

\section{Subgroup analysis}

The group of $T \alpha 1$ administered once per day included six trials with 322 patients and the group of T $\alpha 1$ administered twice per day included two trials with 399 patients. The subgroup analysis showed a significant effect of T $\alpha 1$ once per day on HLA-DR (SMD 0.86, $95 \%$ CI 0.50 to $1.23, p<0.001$ ) with a moderate heterogeneity (Chi 12.24, $\mathrm{I}^{2} 59 \%, p=0.03$ ). However, the effect of T 1 twice per day on HLA-DR was not statistically significant (SMD 2.26, $95 \%$ CI-0.12 to 4.64, $p=0.06$ ) with a significant heterogeneity (Chi 39.47, $\mathrm{I}^{2} 97 \%, p<0.001$ ) (Fig. 5).

\section{The impact on $T$ lymphocyte subsets}

$\mathrm{T} \alpha 1$ showed significantly better effect on $\mathrm{CD}^{+}, \mathrm{CD} 4^{+}$ and $\mathrm{CD} 4^{+} / \mathrm{CD}^{+}$than control, but didn't show difference on $\mathrm{CD}^{+}$. The pooled results were showed in Table 4 . However, there was a high heterogeneity across these studies.

\section{The impact on cytokines}

IL-6 levels Four studies involving 189 patients reported the level of IL-6. There was no significant difference on the level of IL- 6 between T 11 and control group (SMD $-0.32,95 \%$ CI -1.24 to $0.60, p=0.49$ ), and the heterogeneity across the four studies was high (Chi 28 , $\left.\mathrm{I}^{2} 89 \%, p<0.0001\right)$ (Table 5).
IL-10 levels Three studies involving 129 patients reported the level of IL-10. There was a significant difference on the level of IL-10 between T $\alpha 1$ and control group (SMD 1.06, $95 \%$ CI 0.64 to $1.49, p<0.00001$ ). No significant heterogeneity was found across the 3 studies (Chi 2.63, $\mathrm{I}^{2} 24 \%, p=0.27$ ) (Table 5).

TNF- $\alpha$ levels Four studies involving 190 patients reported the level of TNF- $\alpha$. There was a significant difference on the level of TNF- $\alpha$ between T $\alpha 1$ and control group (SMD $-0.47,95 \% \mathrm{CI}-0.76$ to $-0.18, p=0.002$ ). No significant heterogeneity was found across the 5 studies (Chi 2.55, $\mathrm{I}^{2} 0 \%, p=0.47$ ) (Table 5).

Safety of T $\alpha 1$ The included RCTs reported neither T $\alpha 1$ related severe adverse event nor treatment discontinuation due to intolerance or adverse events of $T \alpha 1$.

\section{Discussion}

In this systematic review of RCTs including1354 patients with sepsis, we found benefits of T $\alpha 1$ on both survival and other clinical indicators. We also explored the efficacy of $\mathrm{T} \alpha 1$ on immune parameters.

\section{Overall completeness and applicability of evidence}

The trials were identified following a systematic search of the literature in multi-language databases. Besides English and Chinese databases, we additionally searched

Table 3 The influence on MOF, length of ICU stay and mechanical ventilation days

\begin{tabular}{|c|c|c|c|c|c|c|c|}
\hline & Included studies & Cases & Chi & $P^{2} \%$ & SMD & $95 \% \mathrm{Cl}$ & $P$ \\
\hline MOF & $1[32]$ & 44 & - & - & -0.49 & $-1.09,0.11$ & 0.11 \\
\hline Length of ICU stay & $6[31,33,35,37,39,43]$ & 591 & 34.92 & $86 \%$ & -0.52 & $-1.06,0.01$ & 0.06 \\
\hline Mechanical ventilation days & $6[31,33,35,37-39]$ & 570 & 32.24 & $84 \%$ & -0.37 & $-0.90,0.17$ & 0.17 \\
\hline
\end{tabular}




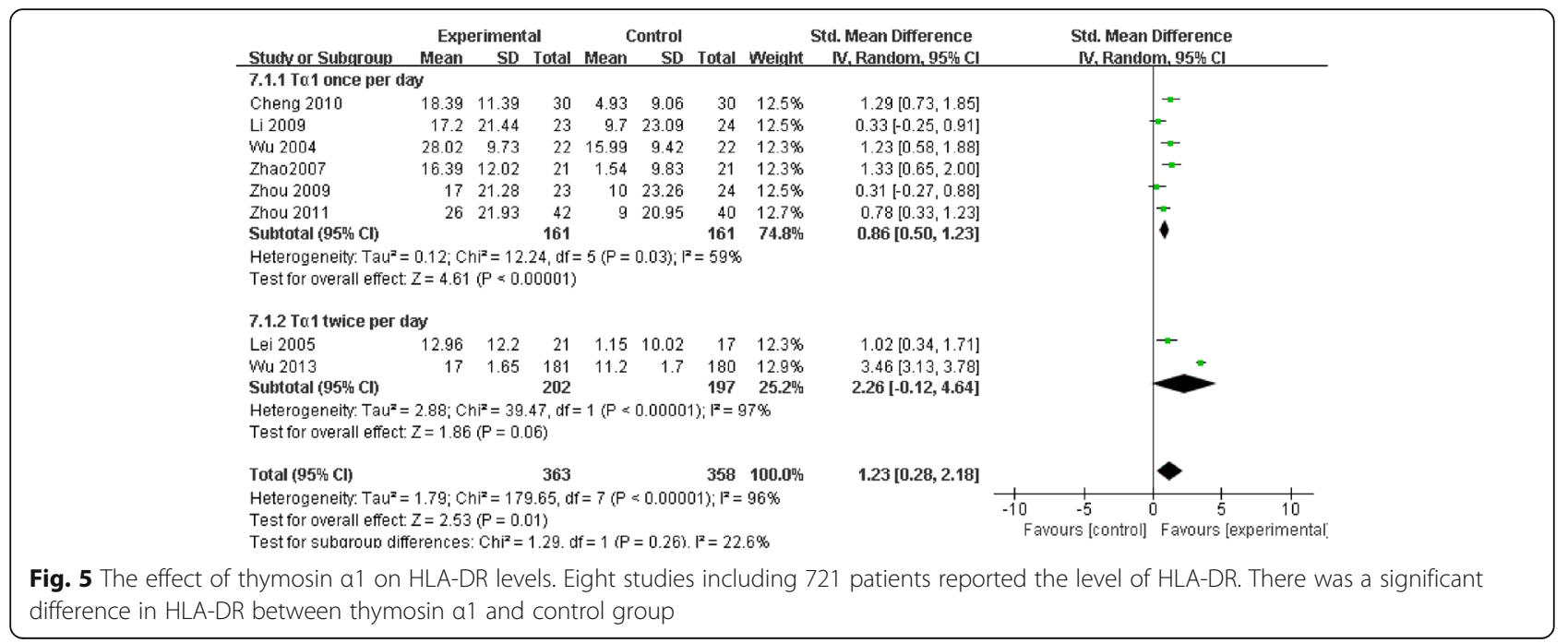

Japanese and Korean database to enhance our systematic review's ability of reflecting international practice. Study inclusion criteria were tightly defined and the metaanalysis was rigorously conducted according to a predefined analysis plan addressing specific hypotheses.

We didn't set limitations on the primary etiologies of sepsis, however, all trials included critically ill patients where a common systemic inflammatory pathway was activated. Therefore, we think that there is a good biologic reason to perform a broad meta-analysis, which also considerably increases the generalizability and usefulness of the review.

The data of lymphocyte subsets and cytokines were collected at the 7th day of treatment course of T $\alpha 1$ in most of the included studies and had the same tendency of favoring T $\alpha 1$ group as 28 days' mortality, which indicates that those data can be served as prognosis indicator for sepsis. Our systematic review is consistent with recent studies indicated that the relationship of cytokines and mortality of sepsis [44-46].

In subgroup analysis, both T $\alpha 11.6 \mathrm{mg}$ once daily and $1.6 \mathrm{mg}$ twice daily decreases mortality, APPACHE II score, ventilation days and ICU days, and they also showed positive effect on lymphocyte subsets and cytokines. Though we didn't carried out comparisons between the two regimens, we recommend T $11.6 \mathrm{mg}$ once daily to be used for cost-effectiveness considerations.
The role of Ta1 in immune modulatory therapy of sepsis It was indicated in a variety of studies that T $\alpha 1$ modulated immune functions through multiple pathways; however, its mechanism was not fully established [47]. Recent studies suggested that $\mathrm{T} \alpha 1$ combines to toll like receptors (TLRs) located in the surface of dendritic cells (DC), and thus activates them into effector cells with the function of stimulating or inhibiting $\mathrm{T}$ cells [48]. As highly specialized type of antigen-presenting cell (APC), $\mathrm{DC}$ activate $\mathrm{CD}^{+}$(total $\mathrm{T}$ cells), $\mathrm{CD}^{+}$(helper $\mathrm{T}$ cells), and $\mathrm{CD}^{+}$(cytotoxic T cells), which is considered as important pathway for $\mathrm{T} \alpha 1$ to reverse immune suppression in sepsis. Moreover, plasmacytoid dendritic cells promote the function of regulatory $\mathrm{T}$ Cells, which increase the production of anti-inflammatory factors, such as IL-10 and TGF- $\beta$, and reduce the pro-inflammatory cytokines, such as IL-2, IL-6 and TNF- $\alpha$, so that to combat against the pro-inflammatory cytokines storm in early period of sepsis and then modulate the over-stimulating of nonspecific immunity in the deferment period later on [49]. HLA-DR is expressed in the surface of B-lymphocytes, macrophages, activated $\mathrm{T}$ lymphocytes and other immune cells, and the decline of HLA-DR expression is proposed as a reflection of immunosuppression in critically ill patients [50].

Our study shows $\mathrm{T} \alpha 1$ increased $\mathrm{CD}^{+}, \mathrm{CD}^{+}$, and $\mathrm{CD} 4^{+} / \mathrm{CD}^{+}$, as well as the level of HLA-DR, which

Table 4 The influence on lymphocyte subsets

\begin{tabular}{|c|c|c|c|c|c|c|c|}
\hline Lymphocyte subsets & Included studies & Cases & Chi & $1^{2} \%$ & SMD & $95 \% \mathrm{Cl}$ & $P$ \\
\hline $\mathrm{CD} 3$ & $9[25,28,31,33,35,36,38,42,43]$ & 521 & 56.12 & $86 \%$ & 0.84 & $0.35,1.33$ & 0.0008 \\
\hline CD4 & $14[25-28,30,31,33-38,42,43]$ & 779 & 51.01 & $75 \%$ & 0.80 & $0.50,1.10$ & $<0.0001$ \\
\hline CD8 & $12[25,26,28,30,31,33-37,42,43]$ & 695 & 62.64 & $82 \%$ & -0.27 & $-0.64,0.10$ & 0.16 \\
\hline $\mathrm{CD} 4 / \mathrm{CD} 8$ & $13[25,27,28,30,31,33,35-39,42,43]$ & 1038 & 102.37 & $88 \%$ & 0.62 & $0.22,1.02$ & $<0.0001$ \\
\hline
\end{tabular}


Table 5 The influence on cytokines (interleukins and TNF-a)

\begin{tabular}{llllllll}
\hline Cytokines & Included studies & Cases & Chi & I $^{2} \%$ & SMD & $95 \%$ Cl & $P$ \\
\hline IL-6 & $4[27,28,34,41]$ & 189 & 28 & $89 \%$ & -0.32 & $-1.24,0.6$ & 0.49 \\
IL-10 & $3[27,28,34]$ & 129 & 2.63 & $24 \%$ & 1.06 & $0.64,1.49$ & $<0.00001$ \\
TNF-a & $4[28,29,34,35]$ & 190 & 2.55 & $0 \%$ & -0.47 & $-0.76,-0.18$ & 0.002 \\
\hline
\end{tabular}

comply with the results of basic research. However, T $\alpha 1$ did not demonstrate a significant impact on $\mathrm{CD}^{+}$. As to the influence on cytokines, our study showed that T $\alpha 1$ decreased the level of TNF- $\alpha$ and increased IL-10, but had no significant effect on IL-6. Besides that, it was suggested by both basic research and clinical trials that multiple kinds of other cytokines experience significant changes with the progress of sepsis, including IL-2, IL-3, IL-4 and IFN- $\gamma$ etc. However, those cytokines were barely evaluated in the included studies. Therefore, more studies, both fundamental and clinical are needed for further understanding the immune-modulatory effect of T $\alpha 1$ on different immune cells and cytokines with the progress of sepsis.

\section{Safety of Ta1}

According to package insert of $T \alpha 1$, the rate of adverse reactions of $\mathrm{T} \alpha 1$ is less than $1 \%$ across all its indications. The reported ADRs include pain, redness, and transient muscle atrophy in injection site, multiple joint pains with swelling, and rash. Both $\mathrm{Li}$ [51] and our systematic reviews included adverse reactions to evaluate Tal's tolerability, and no severe ADRs were recorded in the included clinical trials.

\section{Comparisons with published review}

Three similar systematic reviews had been published recently [51-53]. All of them took T $\alpha 1$-based immune modulatory therapy as intervention, which means they included not only T $\alpha 1$, but also concomitantly used ulinastatin. Han [52] evaluated combination of ulinastatin and T $\alpha 1$, but not $T \alpha 1$ monotherapy. For T $\alpha 1$ monotherapy groups, the recently published reviews included fewer studies than ours, which may because they searched less Chinese literature database. For outcomes, all the systematic reviews took mortality as primary outcomes, while durations of mechanical ventilation and ICU stay were evaluated in both Han and Feng's review, and APACHE II in Feng's review. Compared to that, our study also included MOF score, hoping to provide some hint on efficacy of T $\alpha 1$ in organ dysfunction in sepsis though we didn't come to a definite conclusion because of the limited number of included study. Furthermore, the studies by $\mathrm{Li}$ and Feng $[51,53]$ failed to include immune indicators, while Han evaluated TNF- $\alpha$ and IL-6 [52]. We considered more immune indicators since it was implicated in previous studies shat T $\alpha 1$ showed pleiotropic effects on immune system [54]. We hope the meta-analysis of immune parameters will be helpful to find out the factors to predict the efficacy of $T \alpha 1$ in sepsis. Furthermore, providing communitive clinical evidence as meta-analysis may indicate directions for subsequent fundamental researches on the immunomodulatory mechanism of T $\alpha 1$ in treating sepsis.

We didn't include studies evaluating efficacy of concurrent use of $T \alpha 1$ and ulinastatin, except for the studies where ulinastatin were used as background therapy. According to present study, it seems that immunemodulatory effects between T $\alpha 1$ and ulinastatin overlap each other especially when it comes to their effects on proinflammatory mediators. To figure out to what extent $T \alpha 1$ is responsible for the beneficial effects noted in the clinical trials, we decided to focus on the studies evaluating the efficacy of T $\alpha 1$ monotherapy. Future studies providing head-to-head comparison between T $\alpha 1$ and ulinastatin may be beneficial to further discover the pathway by which immune modulators pose influence on physiopathology of sepsis.

\section{Limitations of the review}

The meta-analysis combined data from a group of predominantly underpowered single center studies. Although there was minimal heterogeneity among trial results on mortality, we are aware that we pooled clinical trials with high risk of bias, thus, the validity of our meta-analysis may be criticized. Another concern is that great heterogeneity existed in the meta-analysis of lymphocyte subsets and cytokines, which may be related to the different measure methods across the included studies. We used standardized mean deviation and carried out sensitivity analysis, and it was showed that the pooled results were stable after removal the studies with heterogeneity.

In 2015, the Society of Critical Care Medicine proposed the new definition of sepsis, which demonstrated sepsis as a life-threatening organ dysfunction (OD) due to a dysregulated host response to infection. SOFA was the major tool to evaluate organ dysfunction, and was shown to be associated with prognosis of sepsis [55]. We included SOFA in our secondary outcomes, regretfully, none of the included studies used SOFA to evaluate efficacy of $\mathrm{T} \alpha 1$.

\section{Conclusion}

In summary, T $\alpha 1$ may have some benefits in reducing 28 day mortality, deceasing APPACHE II score and 
modulating immune parameters in sepsis patients, however, the quality of evidence is low. More high-quality studies are needed to confirm T $\alpha 1$ efficacy in improving clinical outcomes and provide comprehensive understanding of its immumodulatory role in sepsis.

\section{Key messages}

- In sepsis patients, $T \alpha 1$ decreased 28 days mortality on the basis of regular therapy.

- Both Ta1 $1.6 \mathrm{mg}$ once daily and $1.6 \mathrm{mg}$ twice daily had the effect to decrease mortality and APPACHE II score.

- T $\alpha 1$ increased the level of IL-10 among sepsis patients.

- T $\alpha 1$ reduced the level of TNF- $\alpha$ among sepsis patients.

- Sepsis patients benefited from To1 as immunomodulatory treatment.

\section{Abbreviations}

IL: Interleukin; 95 \% Cls: 95 \% confidence intervals; APACHE II: Acute physiology and chronic health evaluation II; mHLA-DR: Monocyte human leukocyte antigen-DR; MODS: Multiple organ dysfunction syndrome; RCT: Randomized controlled trial; RR: Relative risk; SMD: Standard mean difference; SR: Systematic review; TNF: Tumor necrosis factor;

Ta1: Thymosin al

\section{Acknowledgements}

We thank Dr. Yiqing Song for his help in searching Japanese and Korean literature.

\section{Funding}

This work was supported by the National Natural Science Foundation of China (81372043) and Beijing Natural Science Foundation (7162199) China.

\section{Availability of data and materials}

All the data supporting our findings is contained within the manuscript.

\section{Authors' contributions}

Study design: XZ and FL. Data analysis: HMW, FL and TSW. Manuscript writer: HMW and FL. Data collection: HMW, FL and YMZ. Manuscript revision: HMW, FL, TSW and XZ. All our authors have read and approved of the final version of our manuscript.

\section{Authors' information}

FL: MSC, clinical pharmacist, is qualified in clinical drug therapy and has the experience of publishing systematica review in peer-reviewed journals. HMW: MSc, clinical pharmacist. TW: Pharm D, assistant professor of clinical pharmacy, has the experience of publishing systematica review in peer-reviewed journals. YMZ: Pharmacy student. XZ: MD, Professor, has been working as specialist in critical care for 25 years.

\section{Competing interests}

The authors declare that they have no competing interests.

\section{Consent for publication}

Our manuscript doesn't contain any individual person's data, so it's not applicable in this section.

\section{Ethics approval and consent to participate}

Our manuscript is a secondary-research, which dosn't contain any individual patient data, so that no consent to participate and ethics approvel is needed in theory. We failed to find national guidlines which contains special statement for the ethics of systematic review. We consulted the ethics committee of Peking
University Third Hospital, and were informed that no formal ethics approval was required for this research.

\section{Author details}

'Department of Pharmacy, Peking University Third Hospital, Beijing 100191, China. ${ }^{2}$ Department of Pharmacy, Yanqing Teaching Hospital of Capital Medical University/Yanqing County Hospital, Beijing 102100, China. ${ }^{3}$ Department of Clinical Pharmacy and Pharmacy Administration, School of Pharmaceutical Sciences, Peking University, Beijing 100191, China. ${ }^{4}$ Department of Critical Care Medicine, Peking University Third Hospital, 49 North Garden Road, Haidian District, Beijing 100191, China.

Received: 28 September 2015 Accepted: 9 September 2016

Published online: 15 September 2016

References

1. Phua J, Du B, Tang Y, Divatia JV, Tan CC, Gomersall CD. Management of severe sepsis in patients admitted to Asian intensive care units: prospective cohort study. BMJ. 2011;342:d3245.

2. Zhang LY, Chen J, Jiang DP, Zhang P. Adjuvant treatment with crude rhubarb for patients with systemic inflammation reaction syndrome/sepsis: A meta-analysis of randomized controlled trials. J Crit Care. 2015:30:282-9.

3. Tang CH, Middleton PM, Savkin AV, Chan GS, Bishop S, Lovell NH. Non-invasive classification of severe sepsis and systemic inflammatory response syndrome using a nonlinear support vector machine: a preliminary study. Physiol Meas. 2010;31:775-93.

4. Darmochwal-Kolarz D, Kludka-Sternik M, Tabarkiewicz J, Kolarz B, Rolinski J, Leszczynska-Gorzelak B, et al. The predominance of Th17 lymphocytes and decreased number and function of Treg cells in preeclampsia. J Reprod Immunol. 2012:93:75-81.

5. Brunialti MK, Santos MC, Rigato O, Machado FR, Silva E, Salomao R. Increased percentages of Thelper cells producing $\mathrm{LL}-17$ and monocytes expressing markers of alternative activation in patients with sepsis. PLoS One. 2012;7:1-10.

6. Cao YZ, Tu YY, Chen X, Wang BL, Zhong YX, Liu MH. Protective effect of Ulinastatin against murine models of sepsis: inhibition of TNF- $a$ and IL-6 and augmentation of IL-10 and IL-13. Exp Toxicol Pathol. 2012;64:543-7.

7. Tuthill C, Rios I, De Rosa A, Camerini R. Thymosin a1 continues to show promise as an enhancer for vaccine response. Ann N Y Acad Sci. 2012;1270:21-7.

8. Serafino A, Pica F, Andreola F, Gaziano R, Moroni N, Moroni G, et al. Thymosin a1 activates complement receptor-mediated phagocytosis in human monocyte-derived macrophages. J Innate Immun. 2014;6:72-88.

9. Matteucci C, Minutolo A, Sinibaldi-Vallebona P, Palamara AT, Rasi G, Mastino A, Garaci E. Transcription profile of human lymphocytes following in vitro treatment with thymosin a1. Ann N Y Acad Sci. 2010;1194:6-19.

10. Lunin SM, Novoselova EG. Thymus hormones as prospective anti-inflammatory agents. Expert Opin Ther Targets. 2010;14:775-86.

11. Këlliçi S, Burazeri G. Thymosin a1: a promising molecule for important clinical applications. Med Arh. 2009;63:48-50.

12. Goldstein AL, Goldstein AL. From lab to bedside: emerging clinical applications of thymosin a1. Expert Opin Biol Ther. 2009;9:593-608.

13. Rost KL, Wierich W, Masayuki F, Tuthill CW, Horwitz DL, Herrmann WM. Pharmacokinetics of thymosin a1 after subcutaneous injection of three different formulations in healthy volunteers. Int J Clin Pharm Th. 1999:37:51-7.

14. Ciancio A, Rizzetto M. Thymalfasin in the treatment of hepatitis B and C. Ann N Y Acad Sci. 2010;1194:141-6.

15. Chen H, He MY, Li YM. Treatment of patients with severe sepsis using ulinastatin and thymosin a1: a prospective, randomized, controlled pilot study. Chin Med J (Engl). 2009:122:883-8.

16. Yumin L, Hao C, Xun L, Wence Z, He M, Chiriva-Internati M, et al. A new immunomodulatory therapy for severe sepsis: Ulinastatin Plus Thymosin a1. J Intensive Care Med. 2009;24:47-53.

17. Zhang Y, Chen H, Li YM, Zheng SS, Chen YG, Li LJ, et al. Thymosin a1 and ulinastatin-based immunomodulatory strategy for sepsis arising from intraabdominal infection due to carbapenem-resistant bacteria. J Infect Dis. 2008;198:723-30.

18. Levy MM, Fink MP, Marshall JC, Abraham E, Angus D, Cook D, et al. 2001SCCM/ESICM/ACCP/ATS/SIS International Sepsis Definitions Conference. Crit Care Med. 2003;31:1250-6.

19. http://www.clinicaltrials.gov. Accessed 19April 2016.

20. http://www.happyhaksul.com/search/. Accessed 12 February 2015. 
21. http://handbook.cochrane.org/chapter_8/table_8_5_d_criteria_for_judging_ risk_of_bias_in_the_risk_of.htm. Accessed 6 May 2015.

22. Higgins JP, Thompson SG, Deeks JJ, Altman DG. Measuring inconsistency in meta-analyses. BMJ. 2003;327:557-60.

23. Hozo SP, Djulbegovic B, Hozo I. Estimating the mean and variance from the median, range, and the size of a sample. BMC Med Res Methodol. 2005;20:1-10

24. Mai JZ, Li H, Fang JQ, Liu XQ, Rao X. Estimation of Fail-Safe Number in Meta-Analysis. J Evid Based Med (Chin). 2006;5:297-303.

25. Chen XL, Lin JD, Lin G. Effect of thymosin a1 on T lymphocytes subpopulation of patients with sepsis. China Prac Med. 2009;4:1-3.

26. Cheng $A B$, Qiu F, An LH, Fan YX, Zhang YL. Effect of thymosin a1 on cellular immune of patients with sepsis. Jiang su Med J. 2010;36:853-4.

27. Gui CM, Ai RH, Zhang LN. Effectiveness of thymosin a1 therapy and its effects on immune function in the patients with sepsis. Chin J Crit Care Med. 2012;32:255-7.

28. Hu XL, Zhao YZ, Yu BJ, Ma J, Ren JA, Li JS. Effect of thymosin al immune and cytokines in patients with abdominal sepsis. Chin J of Pra Sur. 2007;27:555-7.

29. Gong ZH, Yao J, Yang J, Ji JF, Xiang T. Clinical effects of Xuebijing combined with thymosin a1 in burn patients with sepsis. Chongqing Med. 2011;40:339-40.

30. Fan JB, Xia MC, Teng XK. Influence of Thymosin a1 on Immune Function of Elderly Patients with Sepsis. J Med Mol Biol. 2014;11:347-9.

31. Li YN, Zhou LX, Qiang XH, Yu TO, Mao KJ, Fang B, et al. Effect of continuous blood purification and thymosin a1 on the cellular immunity in patients with severe sepsis: a prospective, randomized, controlled clinical trial. Chin Crit Care Med. 2009;21:139-42.

32. Wu JN, Fang Q. Immune regulation mechanism of thymosin a1 on severe sepsis patients. Chin Crit Care Med. 2004;24:815-6.

33. Zhang Z, Li MQ, Xu JY, Lu F, Li L. The efficacy of thymosin a 1 for sepsis patients with ARDS. Med Inno Res. 2006;3:92-3.

34. Zhao MY, Cao YH, Fei DS, Kong WL, Yu KJ. Influence of thymosin a1 on cellular immunity in the patients with severe sepsis. Chin J Crit Care Med. 2007;27:206-7.

35. Zhou LX, Tan JJ, Li YN, Luo HT, Shao YH, Qiang XH, et al. Immune and inflammation confusion in severe sepsis and effects of biimmunomodulation therapy: a prospective, randomized, controlled clinical trial. Natl Med J China. 2009:89:1028-33.

36. Zhou Q, Guo GY. Clinical study of the immunopotentiation therapy in the patients with severe sepsis. China Med Herald. 2011;8:54-9.

37. Lei S, Wu YC, Chen JH, Wang LC, Wu JN, Ye XH. Application of thymosin a1 to the patients with severe hospital acquired pneumonia. Chin J Care Med. 2005;25:716-9

38. Chen J. Effects of thymosin $a_{1}$ on cell immunity function in patients with septic shock. Chin Crit Care Med. 2007;19:153-5.

39. Wu JF, Zhou LX, Liu JY, Ma G, Kou QY, Chen J, et al. The efficacy of thymosin a1 for severe sepsis (ETASS): a multicenter, single-blind, randomized and controlled trial. Crit Care. 2013;17:R8.

40. Wu JF, Tang ZX, Chen J, Ouyang B, Chen MY, Guan XD. Changes of TLR2, TLR4 and MyD88 mRNA expressions on peripheral blood mononuclear cell in severe sepsis patients during treatment with thymosin a1. Chin Arch Gen Surg. 2014;18:270-4.

41. Zhang BJ, Wu TJ, Qu AJ, Tian H, Zhang LN. The efficacy of thymosin a1 on the expression of inflammatory cytokines for sepsis patients. Chin J Crit Care Med. 2014;34:22-4.

42. Lu FP, Chen W, Zhen J, Ma L. Changes of lymphocyte subsets in elderly patients with sepsis before and after immune modulation therapy. J Jilin Univ (Earth Sci Ed). 2015:41:994-7.

43. Zhu SJ, Weng QY, Wu WW, Rao SS. Clinical efficacy of adjuvant therapy with thymosin a1 and effect to cellular immune function and T-like receptor in patients with SIAI. Chin J Immunol. 2015;31:1674-82.

44. McGuire TR, Reardon NT, Bogard K, Plumb TJ, Bultsma CJ, Nissen SW, et al. IL6 plasma concentrations in patients with sepsis receiving SLED and antibiotics: a predictor for survival. In Vivo. 2014;28:1131-4.

45. Lekkou A, Mouzaki A, Siagris D, Ravani I, Gogos CA. Serum lipid profile, cytokine production, and clinical outcome in patients with severe sepsis. J Crit Care. 2014;29:723-7.

46. Fjell CD, Thair S, Hsu JL, Walley KR, Russell JA, Boyd J. Cytokines and signaling molecules predict clinical outcomes in sepsis. PLoS One. 2013; 8:e79207.
47. Caraci E, Favalli C, Pica F, et al. Thymosin alpha 1:from bench to bedside. Ann NY Acad Sci, 2007,1112:225-234

48. Giacomini E, Severa M, Cruciani M, Etna MP, Rizzo F, et al. Dual effect of Thymosin a1 on human monocyte-derived dendritic cell in vitro stimulated with viral and bacterial toll like receptor agonists. Expert Opin Biol Ther. 2015;15:S59-70

49. Deng M, Ma T, Yan Z, Zettel KR, Scott MJ, Liao H, et al. Toll-like Receptor 4 Signaling on Dendritic Cells Suppresses Polymorphonuclear Leukocyte CXCR2 Expression and Trafficking via Interleukin 10 During Intra-abdominal Sepsis. J Infect Dis. 2016;213(8):1280-8.

50. Monneret G, Lepape A, Voirin N, Bohé J, Venet F, Debard AL, et al. Persisting low monocyte human leukocyte antigen-DR expression predicts mortality in septic shock. Intensive Care Med. 2006;32(8):1175-83.

51. Li CC, Bo LY, Liu QQ, Jin FG. Thymosin a1 based immunomodulatory therapy for sepsis: a systematic review and meta-analysis. Int J Infect Dis. 2015;33:90-6.

52. Han $D$, Shang $W$, Wang $G$, Sun $L$, Zhang $Y$, Wen $H$, et al. Ulinastatin- and thymosin a1-based immunomodulatory strategy for sepsis: A meta-analysis. Int Immunopharmacol. 2015;29(2):377-82

53. Feng Z, Shi Q, Fan $Y$, Wang $Q$, Yin W. Ulinastatin and/or thymosin a1 for severe sepsis: A systematic review and meta-analysis. J Trauma Acute Care Surg. 2016;80(2):335-40.

54. Romani L, Moretti S, Fallarino F, Bozza S, Ruggeri L, Casagrande A, Aversa F, Bistoni F, Velardi A, Garaci E. Jack of all trades: thymosin a1 and its pleiotropy. Ann N Y Acad Sci. 2012;1269:1-6.

55. Singer M, Deutschman CS, Seymour CW, Shankar-Hari M, Annane D, Bauer $M$, et al. The Third International Consensus Definitions for Sepsis and Septic Shock (Sepsis-3). JAMA. 2016;315(8):801-10.

\section{Submit your next manuscript to BioMed Central and we will help you at every step:}

- We accept pre-submission inquiries

- Our selector tool helps you to find the most relevant journal

- We provide round the clock customer support

- Convenient online submission

- Thorough peer review

- Inclusion in PubMed and all major indexing services

- Maximum visibility for your research

Submit your manuscript at www.biomedcentral.com/submit
C Biomed Central 